\title{
'n Allernoodsaaklike boek vir die huweliks- en gesinslewe
}

Book Title:

Die allernoodsaaklikste derde party in die huwelik en gesin

Book Cover:

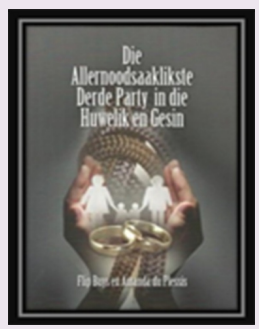

Authors:

Flip Buys

Amanda L. du Plessis

ISBN:

978-0-86955-217-9

\section{Publisher:}

Potchefstroom Theological Publications, Potchefstroom, 2014, R135.00.

*Book price at time of review

\section{-}

Review Title:

'n Allernoodsaaklike boek vir die huweliks- en gesinslewe

\section{Reviewer:}

Jannes C. van Dyk ${ }^{1}$

\section{Affiliation:}

${ }^{1}$ Reformed Church

Ventersdorp

Email:

jannes.vandyk@gmail.com

Postal address:

PO Box 97, Ventersdorp

2710, South Africa

How to cite this book review: Van Dyk, J.C., 2014, "n

Allernoodsaaklike boek vir die huweliks- en gesinslewe', In die Skriflig 48(1), Art. \#1904, 1 page. http://dx.doi. org/10.4102/ids.v48i1.1904

\section{Read online:}

Scan this $Q R$

code with your

smart phone or

mobile device

to read online.
Uit die pen van Flip Buys en Amanda du Plessis kom 'n allernoodsaaklike boek vir die huweliks- en gesinslewe. Hulle deel hierin nie alleen kennis en bedieningservaring nie, maar ook -sonder om dit direk te noem - van hulle eie lewenservaring: die werk wat God deur sy Woord en Gees in húlle lewe gedoen het. Belangrike temas soos kommunikasie en konflikhantering, woede en aggressie, finansies, seksuele eenheid, ouerskap, vriendskapsverhoudings tussen seuns en dogters en -'n baie belangrike hoofstuk - kinders se verantwoordelikhede teenoor hulle ouers, word in hierdie publikasie aangeraak.

Elke hoofstuk begin met ' $n$ kort, bondige inleiding waarmee die leser kan identifiseer. Dit stel die basiese beginsels in die Skrif. Hierdie beginsels word verder in 'n Bybelstudie oor die tema van die hoofstuk uitgewerk. Daarna volg by sommige hoofstukke interessante vrae waar die lesers hulle kan toets. Ná 'n onderneming wat egpare kan onderteken, word die hoofstukke met 'n gebed afgesluit.

Die allernoodsaaklikste derde party in die huwelik en gesin vul inderdaad 'n leemte wat onder Afrikaanssprekendes bestaan, omdat hierdie nie net nog 'n selfhelp-boek is waarna egpare in desperaatheid kan gryp nie. In hierdie boek kom God uit sy Woord aan die woord. Omdat God aan die woord kom, is dit ook belangrik dat die lesers begelei moet word om die Bybel met die Bybelstudies reg te gebruik. In sommige gevalle is daar teksverwysings wat nie met die skopus van die teksgedeelte rekening hou nie. Met die hulp en leiding van 'n predikant of berader sal egpare in hierdie enkele gevalle egter nogtans die stem van die Here kan hoor. Die tegniese versorging van die manuskrip het ongelukkig enkele foute laat deurglip. Daar word byvoorbeeld op bl. 37 na 1 Petrus 4:10 verwys as die gelykenis van die talente. Alhoewel die teksgedeelte oor genadegawes handel, is dit allermins ' $n$ gelykenis oor talente (Matt 25:14 e.v.). ' $n$ Laaste voorbeeld is dié van bladsy 126. Die geskiedenis van Eli en sy seuns vind 'n mens in 1 Samuel 22:29-30 en nie in 1 Samuel 2 nie.

Egpare wie se huweliksbootjie deur stormsee vaar, sal beslis by hierdie boek baat vind, maar ander egpare kan hierdie boek ook met groot vrug vir 'n verdieping in hulle huwelikslewe gebruik. Predikante en beraders kan met groot vrymoedigheid die inhoudsopgawe van hierdie boek as 'n agenda vir hulle pastorale werk gebruik onder egpare wie se huwelikslewe stormagtige tye deurgaan. Die inhoud hiervan sal tot sinvolle ontmoetings bydra. 